\title{
Use of Historical Yield Data to Forecast Range Herbage Production
}

\author{
C.L. HANSON, J.R. WIGHT, J.P. SMITH, AND S. SMOLIAK
}

\begin{abstract}
An analysis of the 51-year herbage yield series from the Manyberries Range Experimental Farm in southeastern Alberta showed that there was a slight dependency between current year's herbage yield and previous year's yield. The analysis showed that the conditional probability of a below-average yield following a belowaverage yield year was about the same as the unconditional probability of having a below-average yield in any given year. The conditional probability of an above-average yield following a year with a below-average yield was significantly below the unconditional probability of having an above-average yield in any year. The probability of an above-average yield following a year with an above-average yield was significantly greater than the unconditional probability.
\end{abstract}

There have been numerous studies on the effects of drought on vegetation and animal life, a summary of which can be found in Hounam et al. (1975). Periodic droughts are part of the rangeland environment. Their occurrence can drastically reduce both plant and animal populations. In the northern Great Plains, the 1930's drought resulted in severe reductions in plant density and available forage (White et al. 1978). Such forage losses complicate the problems of range management. These problems are further intensified by the unpredictability of occurrence, intensity, and duration of drought. Also of importance to range resource managers are the carryover or residual effects of drought on forage availability.

The purpose of this paper was to determine if there was a dependency between current and the previous 1 or 2 years'yields. Of particular interest was the effect of below-average annual herbage yields on the probability of below-average yields in subsequent years.

\section{Data Set}

The herbage yield data used in this study were obtained from the Manyberries Range Experimental Farm in the mixed prairie region (Coupland 1950) of southeastern Alberta. Principal species included needle-and-thread (Stipa comata), western wheatgrass (Agropyron smithii), blue grama (Bouteloua gracilis), and Junegrass (Koeleria cristata) (Smoliak 1956). Soils at the study site were classified as Brown Chernozemic with a loam texture (Dormaar 1975)

Annual yield was measured at peak standing crop as the total herbage clipped at ground level. Yield information was available for the period 1930 through 1980, with the exception of 1941, 1944, 1945 , and 1946. Because a continuous record was desirable for this study, yields were estimated for the 4 missing years, using the linear relationship between May plus June precipitation and yield given

\footnotetext{
Authors are agricultural engineer, range scientist, and hydrologist, respectively; USDA, Agr. Res. Serv., 1175 South Orchard, Suite 116, Boise, Idaho 83705; and research scientist, Plant Science Section, Research Station, Lethbridge, Alberta, T1J 4B1.

Contribution from the Northwest Watershed Research Center, Agr. Res. Serv., USDA, and Bureau of Land Management, USDI; in cooperation with the Agr. Exp. Sta., University of Idaho, Moscow, Idaho 83843.

Manuscript received November $5,1981$.
}

by Smoliak (1956). The time series of annual herbage yields is shown in Figure 1. Figure 2. shows the relative frequency of exceeding or not exceeding a yield in any given year. The yields averaged $388 \mathrm{~kg} / \mathrm{ha}$ and ranged from a low of $96 \mathrm{~kg} / \mathrm{ha}$ in 1961 , to a high or $924 \mathrm{~kg} / \mathrm{ha}$ in 1942. Additional information about the vegetation on the study site and harvesting methods can be found in Smoliak (1956).

\section{Statistical Analysis}

Standard regression techniques were used to determine the linear dependence of the current year's yield on the 2 previous year's yields, lag 1 and lag 2 serial correlations, and to test the significance of the linear dependence (Chow 1964; Haan 1977). The same procedures were used to investigate the linear dependence between the current year's precipitation (August 1 through July 31) and the previous 2 year's precipitation.

The above analyses indicated that a 3-state Markov chain may be used to describe the stochastic process. A Markov chain is a stochastic process described by transition probabilities of going from one state to another with the property that a given state depends on its value at time $t-1$, and not on how the value at $t-1$

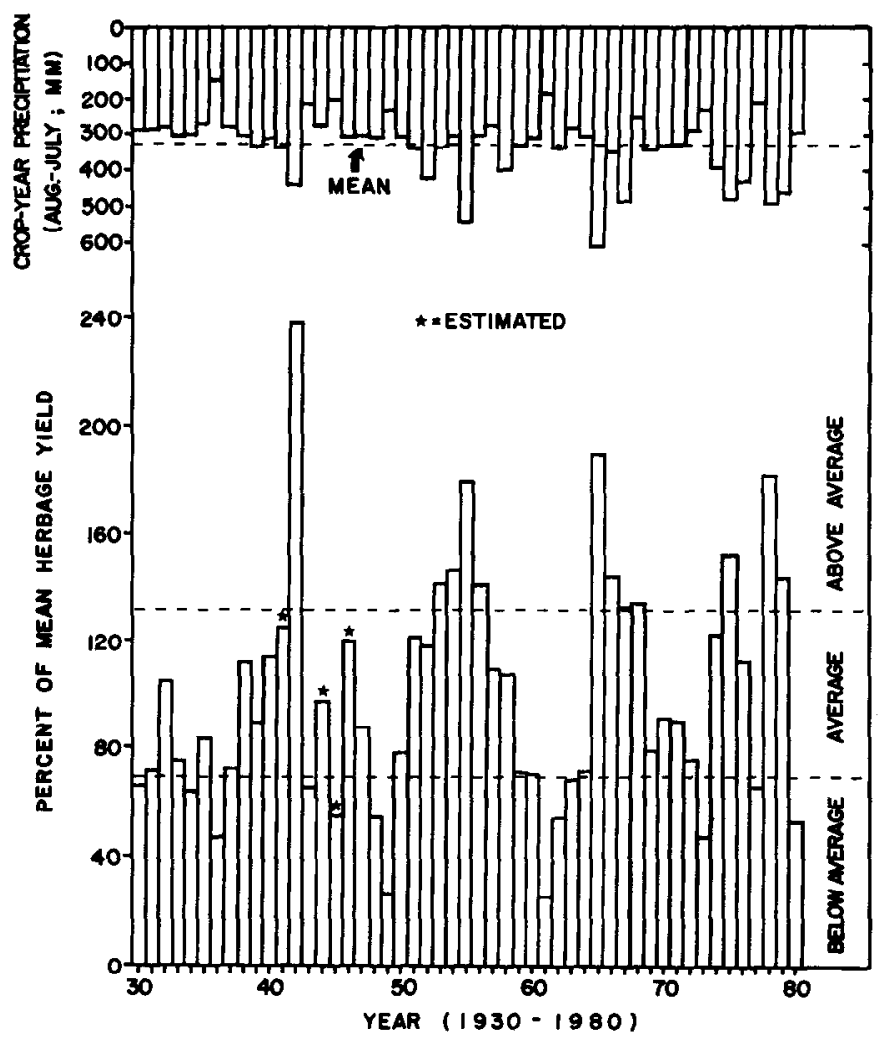

Fig. 1. Annual yields expressed as percent of mean-Manyberries, Alberta. 


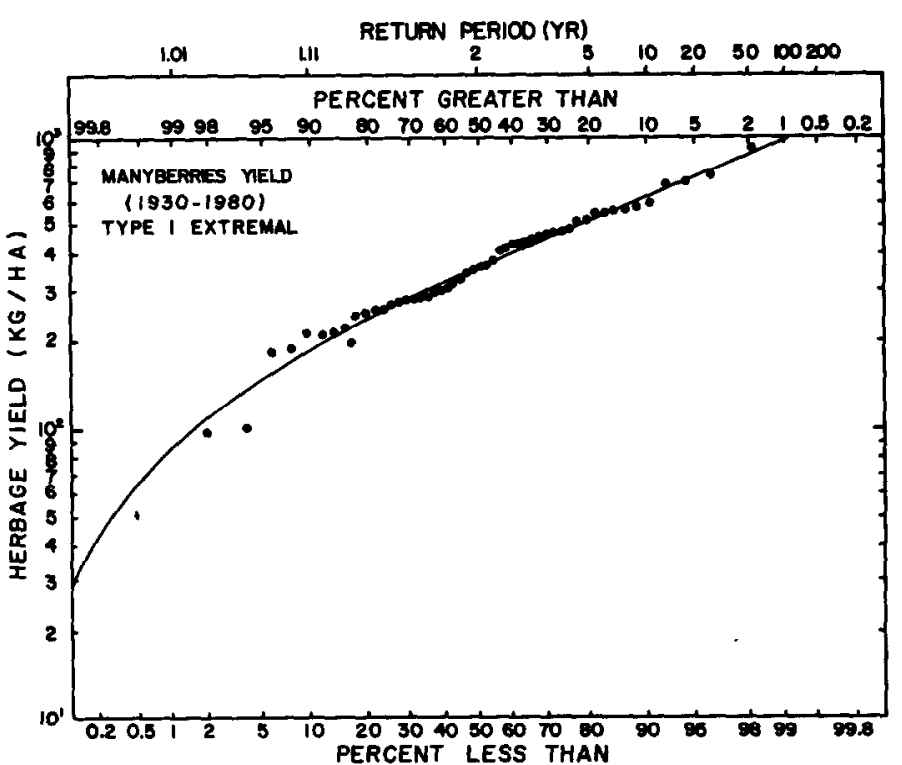

Fig. 2. Annual herbage yield exceedence probability curve.

arrived at that state. The transition or conditional probability that a process $X_{\mathrm{t}}$ at time $t$ is in state $j$, given that the process is in state $i$ at time $t-1$ can be written.

$$
P\left[X_{\mathrm{t}}=j \mid X_{\mathrm{t}-1}=i\right]
$$

The unconditional probability, denoted by $\left[X_{\mathrm{t}}=j\right]$, is the probability that the process will be in state $j$ at time $t$ without any knowledge of the state of the system at time $t-1$.

The "below-average" state was defined to include all yields less than 0.7 of the long-term average yield ( $\bar{F}$; the "average yield" state included yields equal to $0.7 \vec{P}$ through $1.3 \bar{Y}$; and the aboveaverage" state included all yields greater than $1.3 Y$. The belowaverage state is somewhat similar to the drought categories established by Hurtt (1951) at Miles City, Montana, where he found that drought conditions prevailed when spring and summer growing precipitation was less than 0.7 times the average precipitation for that season. In our study $27 \%$ of the yields were in the below-average state, $49 \%$ in the average state, and $24 \%$ in the above-average state

The conditional and unconditional occurrences for the categories shown in Table 2 were tested using the Chi-square test (Ostle 1963). The occurrences were tested using binomial contingency tables and not as a single table.

\section{Discussion}

The lag 0 and lag 1 cross correlations matrices for crop year precipitation and herbage yield are given in Table 1 . There is a high lag 0 cross correlation ( 0.76 ) between herbage yield and precipitation. The lag I cross correlation maxtrix shows a serial correlation

Table 1. Precipitation and yield, lag 0 and lag 1 , cross correhation matrices.

\begin{tabular}{|c|c|c|}
\hline & \multicolumn{2}{|c|}{ lag 0} \\
\hline & Precipitation & Yield \\
\hline \multirow[t]{3}{*}{$\begin{array}{l}\text { Precipitation } \\
\text { Yield }\end{array}$} & $\begin{array}{l}1.00 \\
0.76\end{array}$ & $\begin{array}{l}0.76 \\
1.00\end{array}$ \\
\hline & \multicolumn{2}{|c|}{ lag 1} \\
\hline & $\begin{array}{l}\text { Precipitation } \\
\text { year }(t)\end{array}$ & $\begin{array}{l}\text { Yield } \\
\text { year }(t)\end{array}$ \\
\hline $\begin{array}{l}\text { Precipitation } \\
\text { Year }(t-1)\end{array}$ & 0.06 & 0.22 \\
\hline $\begin{array}{l}\text { Yield } \\
\quad \text { Year }(t-1)\end{array}$ & 0.15 & 0.32 \\
\hline
\end{tabular}

of 0.32 in the herbage yield series, which was significant at the $5 \%$ level; however, the information obtained from the last year's yields only improved the current year's yield estimates by about $6 \%$ as determined by multiple regression analyses. There was no serial correlation in the precipitation series $(0.06)$. The lag 1 cross correlation between yields and last year's precipitation $(0.22)$ was not significant at the 5\% level. There was no significant lag 2 effects in either the herbage series or the precipitation series.

The data in Table 2 indicated that there is little difference in the conditional probability of a below-average yield year following a below-average yield year, and the unconditional probability of a below-average yield in any given year $(0.31$ vs. 0.27$)$. However, the conditional probability of an average yield year following a belowaverage yield year is somewhat greater than the unconditional probability $(0.62$ vs 0.49$)$. The conditional probability of an aboveaverage yield year following a below-average yield year is very small; only 0.07 as compared to the unconditional probability of 0.24 .

Table 2. The transition probabilities matrix ${ }^{1}$ and the unconditional probabilities calculated from Manyberries herbage yield data.

\begin{tabular}{lccc}
\hline Yield categories & Below-average & Average & Above-average \\
\hline Below-average & 0.31 & 0.62 & 0.073 \\
Average & 0.28 & 0.56 & 0.16 \\
Above-average & 0.17 & $0.25^{4}$ & $0.58^{4}$ \\
& & & \\
\hline $\begin{array}{l}\text { Unconditional } \\
\text { Probabilities }\end{array}$ & .27 & .49 & .24 \\
\hline
\end{tabular}

IThis matrix contains the conditional probabilities. They reflect the effects of the previous year's growing conditions on current year's yield.

${ }^{2}$ The unconditional probabilities assume no yield relationship between years and are based only on random chance.

3Significantly different from the unconditional probability at $20 \%$ level.

¿Significantly different from the unconditional probability at $10 \%$ level.

Other probabilities can be determined from Table 2. For example, the conditional probability of an average yield year following an average yield year is 0.56 ; the unconditional probability is 0.49 . The conditional probability of an above-average yield year following an above-average yield year was 0.58 , while the unconditional probability was only 0.24 .

The probability of an average or above-average yield year following a below-average yield year is 0.62 plus 0.07 , which is 0.69 , and the unconditional probability of an average or above-average yield is 0.49 plus 0.24 , which is 0.73 . This indicates that a belowaverage yield year reduces the probability of a good yield the next year. Also, the probability of an average or above-average yield year following an average yield year is 0.56 plus 0.16 , which is 0.72 , and the probability of an average or above-average yield year following an above-average yield year is 0.25 plus 0.58 , which is 0.83 . This indicates that the probability of a good yield is related to the previous year's yield.

The probability of a run of 3 consecutive below-average yields is 0,07 . The historical record shows only 2 occurrences of 3 consecutive below-average yields during the 51 years of record. As can be seen in Figure 1, these 2 sequences of below-average yields were together in the early 1960 's. The probability of a run of 3 consecutive above-average yields is 0.14 , which is a higher probability of above-average yields being in sequence than belowaverage yields. There were 4 sequences during the 51 year series where there were 3 years of above-average yields. These sequences were in 2 periods, one during the mid 1950's and the other during the late 1960's. The above-average yield years in the late 1960's followed the very low yields of the early 1960's. Because there was no dependency between seasonal precipitation, the dependency between yields must be associated with factors, such as soil water, plant vigor, and other biological factors; but whatever the reasons 
are, they are contained in the historical series.

The herbage-yield, frequency curve (Fig. 2) can be used to estimate the frequency of expected yields. For example, one can expect a yield of up to $510 \mathrm{~kg} / \mathrm{ha}$ once in 5 years, and a yield of up to $640 \mathrm{~kg} / \mathrm{ha}$ once in 10 years. The use of Figure 2 with Table 2 can give the range manager an idea of expected yields, as well as how they are distributed.

\section{Conclusions}

1. The previous year's herbage yield has a significant $(p<0.05)$ effect on the current year's yield with a serial correlation of 0.32 ; however, the past year's yield added only a small amount of information about the current year's yield. The conditional probability of a below-average yield following a year with a belowaverage yield was only slightly higher than the unconditional probability ( 0.31 vs. 0.27$)$. However, the probability of having an average or below-average yield following a year with belowaverage yields was considerably higher $(0.93$ vs. 0.76$)$.

2. There was no significant linear dependence between the current year's yield and the yield 2 years previous.

3. The probability of an above-average yield year following an above-average yield year was considerably greater than that expected due to random chance (0.58 vs. 0.24$)$.

4. These conclusions were based on data from one location and on a data series of only 51 years. Caution should be taken when the probabilities are used to forecast herbage yields. The transition probabilities may be considerably different for other locations. However, the tendency for yields to be higher following average or above-average years, than following below-average years, probably occurs on most range sites. This tendency has potential use in determining management decisions.

\section{Literature Cited}

Chow, V.T. 1964. Handbook of Applied Hydrology. McGraw-Hill Book Co., New York, p. 18-1 to 18-26.

Coupland, R.T. 1950. Ecology of mixed prairie in Canada. Ecol. Mono. 20:271-315.

Dormaar, J.F. 1975. Susceptibility of organic matter of chernoxemic Ah horizons to biological decomposition. Can. J. Soil Sci. 55:473-480.

Haan, C.T. 1977. Statistical Methods in Hydrology. Iowa State University Press, Ames 378 p.

Hounam, C.E., J.J. Burgos, M.S. Kalik, W.S. Palmer, and J. Rodda. 1975. Drought and Agriculture. World Meteor. Organ. Tech. Note No. 138 (WMO-No. 392), Geneva, Switzerland, 27 p.

Hurtt, L.C. 1951. Managing Northern Great Plains cattle ranges to minimize effects of drought. U.S. Dep. of Agr. Circular No. 865, 24 p.

Ostle, B. 1963. Statistics in Research. lowa State University Press, Ames $585 \mathrm{p}$.

Smoliak, S. 1956. Influence of climatic conditions on forage production of shortgrass rangeland. J. Range Manage. 9:89-91.

White, L.M., J.J. Newbauer III, and J.R. Wight. 1978. Vegetational differences on native range during 38 years in eastern Montana. In: Hyder, D.N. (ed.), Proc. First Internat. Rangeland Congress, Aug. 14-18, 1978, Denver, Colo. Soc. Range Manage., Denver, Colo. p. 260-262.

\section{REMOTE SENSING FACULTY POSITION UNIVERSITY OF MINNESOTA}

Professor or Associate Professor of Remote Sensing. Dept of Forest Resources; and Director, Remote Sensing Laboratory, Institute of Agriculture, Forestry and Home Economics.

Position is tenured, 12-month appointment including 30\% teaching, 30\% research, and $40 \%$ administration of the Remote Sensing Lab. Responsibilities include teaching advanced courses in remote sensing and related areas, advising undergraduate and graduate students, conducting research programs through the Agricultural Experiment Station, and conducting noncredit workshops for outreach clientele. As director, perform administrative duties including budget and personnel management, program planning, development of external funding sources, and representation of the lab within and outside of the university. Coordinate and facilitate the application of remote sensing technology on agriculture and natural resources. Share in faculty responsibilities related to academic affairs.

Applicants should have a Ph.D. with strong concentration of coursework in remote sensing and computer application. Academic background and/or work experience in forestry or related natural resource field with at least one degree in forestry preferred. Evidence of satisfactory administrative experience highly desirable. Competence in written and oral communications, computer use, budget management, and personnel management essential.

Salary is competitive and commensurate with experience and qualifications. Position is available 1 April 1983.

Qualified applicants send professional resume and academic transcripts no later than 1 Dec. 1982. Arrange transmittal of 3 letters of reference to be received no later than 6 Dec. 1982. Send to Dr. Alan Ek, College of Forestry, University of Minnesota, $110 \mathrm{C}$ Green Hall, $1530 \mathrm{~N}$. Cleveland Ave., St. Paul, MN 55108. For more information, call Alan Ek at 612/373-0843.

The University of Minnesota is an equal opportunity educator and employer and specifically invites and encourages applications from women and minorities. 